\title{
THE IMPACT OF THE COVID-19 PANDEMIC ON SUPPLY CHAINS IN THE AUTOMOTIVE INDUSTRY
}

\author{
Goran Milovanovic ${ }^{1}$ \\ Tamara Stankovic ${ }^{2}$
}

DOI: https://doi.org/10.31410/LIMEN.2020.51

\begin{abstract}
Health crises have an impact on supply chains, mainly by disrupting their regular activities. In this research, the authors have analyzed the impact that the Covid-19 pandemic has made on business relationships between supply chain partners in the automotive industry and their suppliers, which are mostly from territories where the initial outbreak of the SARS COV 2 virus occurred. The analysis shows that in some cases, there is a strong dependency between the pandemic and production levels. Being dependent prevents supply chains from maintaining stability and causes system vulnerabilities. The authors conclude their work with a thesis on the pronounced impact of the current pandemic on automotive supply chain activities. For the analysis to be complete, it is necessary to monitor changes in production levels further, since data for the current year still does not provide a realistic insight into all the consequences at the supply chain level.
\end{abstract}

Keywords: Supply chains, Covid-19, Automotive industry, Production levels.

\section{INTRODUCTION}

7 he emergence of a new virus, SARS-CoV-2, which caused the Covid-19 pandemic, has greatly changed the opportunities on the global market. Its appearance in the province of Hubei in China caused great fear around the world. The spillover effect occurred very quickly, and other countries became active participants in solving the problem, which in the meantime grew to the level of a pandemic.

Based on various researches on the impacts of the current pandemic on different industry branches, an imposed assumption is that the most pronounced impact is in the domain of the automotive industry. In his paper, the author Shuichi Ishida observes the impact on various industry branches and concludes that the great dependency of production levels in the automotive industry and the current pandemic can be explained through business relations between the world's largest manufacturers and their main suppliers. Until just before COVID19 appeared, most of the world's major automotive manufacturers were sourcing $30-60 \%$ of their components, including modules and subassemblies from China (Ishida, 2020, p.147). Due to the great importance of this topic, the paper will focus on examining the impact of the pandemic on production activities in global chains, and on understanding the consequences and trends. The context in which business takes place today sets a number of limitations, and various indicators point to pessimistic assessments of economic factors whose influence creates trends in the global environment. Based on aggregating industry-level shocks, the OECD estimates a drop in immediate GDP of around 25 per cent (Rio-Chanona, Mealy, Pichler, Lafond \& Farmer, 2020, p.98). This research aims to examine the possibilities of global supply chains in the

Faculty of Economics Nis, Trg kralja Aleksandra Ujedinitelja 11, Serbia

Faculty of Economics Nis, Trg kralja Aleksandra Ujedinitelja 11, Serbia 
automotive industry, and their ability to continue activities despite bad trends. The results of a study by the Institute for Supply Management indicated a serious deterioration in supply chain performances in the ongoing pandemic. In his research proposal, Anne Stall presents a sample of 600 manufacturers, who mostly based their cooperation on first-tier suppliers from China, as many as $57 \%$ indicated lead time extension compared to the previous year, while suppliers indicated their capacity utilization is only $50 \%$ on average. Due to the relevance of everything mentioned above, it is very important to examine the potential effects of the Covid-19 pandemic on the business activities in automotive companies and thus answer the question of its domains and consequences.

\section{CHALLENGES IN THE AUTOMOTIVE INDUSTRY}

The Covid-19 pandemic has actualized supply chain disruptions caused by risks that primarily arose in the health sector. Current research indicates serious consequences of the current pandemic. Logistics operations play a crucial role during the containment effort of an epidemic outbreak as they strengthen the ability of all the parties involved to promptly respond and effectively control the situation (Dasaklis, Pappis \& Rachaniotis, 2012, p.406).

Epidemic outbreaks are a special case of supply chain (SC) risks that is distinctively characterized by a long-term disruption existence, disruption propagations (i.e., the ripple effect), and high uncertainty (Ivanov, 2020, p.1). The great connection and dependency between actors in supply chains can now be seen as a bottleneck that shows significant weaknesses in pandemic conditions. Globalization has enabled decentralized management of global supply chains, which in crises become the subject of efficiency-focused research. The automotive market in particular shows the shortcomings of decentralized operations, and it is considered that the principle of centralization is more suitable, since such health crises show periodicity in their occurrence, and the overall effects of the consequences are growing. Having offshored their manufacturing activities to low-cost countries, many automakers and suppliers are now scrambling to create a centralized management system at a single location in the supply chain (Ishida, 2020, p. 147). Since this crisis is primarily in the health sector, many theorists have based their work on supply chains in the medical equipment procurement segment. The conclusions reached can be partially mapped to all global supply chains, since all of them, regardless of the specific type of product or service, operate in a similar micro and macro environment. Global value chains link the macro-level of international trade, investment, and finance with the meso-level of national and regional economies, and the micro-level of local suppliers, communities, and workers (Gereffi, 2020, p.289). The dominant effects of the pandemic, which can be distinguished among supply chains in any industry branch, relate to large variations in demand, supply and logistics activities. The existence of negative implications is certain, so the question arises as to how it is possible to continue the business and, above all, what changes to implement in order to keep the performance of the chains at the desired level.

In March 2020, most countries were forced to partially or completely close their borders due to the crisis in the health sector. The International Monetary Fund, for instance, predicts that despite massive government support the GDP in the advanced economies will contract by $6 \%$ in 2020 and that almost every country on the globe will face a severe economic recession (Brakman, Garretsen \& Witteloostuijn, 2020, p.1). World trade volumes will contract by more than $10 \%$, and the World Trade Organization (WTO) - in a worst-case scenario - is predicting a more than 30\% decline in world trade (Brakman, Garretsen \& Witteloostuijn, 2020, p.1). The onset of the crisis in the automotive industry almost coincides with the emergence of the SARS 
$\mathrm{CoV}-2$ virus in the Chinese province of Hubei. This province is one of the main industrial bases in which a large number of suppliers are located (slightly more than 100). Based on KPMG, just over $80 \%$ of the world's car production is related to China. It is therefore not surprising that the negative implications of the Covid-19 disease pandemic are spreading quickly to other regions of the world that import parts from their Chinese partners. Since the local Chinese market, due to its instrumental importance in building performance at the global level, exerts a great influence, the analysis of performance in other parts of the world should start from the initial decline in performance and interruptions that occurred in China with the SARS CoV-2 virus. Regardless of the current situation, China remains the largest car market in the world. Based on Accenture research a drop in production in February 2020 of as much as $80 \%$ caused major supply problems. Partners in the US have faced interruptions in the delivery of parts, or in some situations, the lead time has been extended several times. According to ICLG, the US market produced 2.62 million cars in February 2020, while a month later production dropped to 1.7 million cars. The EU market is also suffering huge consequences, where, due to the closure of plants, the number of produced cars has been reduced by 1.2 million. Experts warn that an additional problem in achieving performance in the automotive industry is the planned reduction in world production of 7\% -10\% in the pre-pandemic era (Global Supply Chain Law Blog, 2020). This reduction is related to the supply chain crisis that was current before the Covid-19 pandemic itself. For example, Ford, GM and FCA had suspended their production in the United States and focused their capacity on the production of medical devices. Nissan has suspended complete production in the UK because there was a break in the supply chain due to a drastic drop in demand (Global Supply Chain Law Blog, 2020). Toyota had faced similar problems and halted production in Europe. Officials in this company cite the decline in sales as the main reason for such a decision, but also government restrictions on the movement of people. Honda has temporarily closed its four plants in the US also due to a large drop in demand. Changes have also taken place in the territory of Europe. Thus, the company Renault has closed the plants in Slovenia and Romania.

\section{CHANGES IN PRODUCTION LEVELS}

Statistics indicate a significant decline in production in the automotive industry. In this paper, the focus will be placed on three markets whose production levels are often used in analysis. Relevant information is shown in table 1.

Table 1. Production levels by quarters

\begin{tabular}{|c|c|c|c|c|c|c|}
\hline \multirow{2}{*}{ Market } & \multicolumn{7}{|c|}{ Production levels by years/quarters } \\
\cline { 2 - 7 } & $\mathbf{2 0 1 9 / Q 1}$ & $\mathbf{2 0 1 9 / Q 2}$ & $\mathbf{2 0 1 9 / Q 3}$ & $\mathbf{2 0 2 0 / Q 1}$ & $\mathbf{2 0 2 0 / Q 2}$ & $\mathbf{2 0 2 0 / Q 3}$ \\
\hline Europe & 5.603 .214 & 11.263 .935 & 15.954 .001 & 4.658 .408 & 6.943 .160 & 11.286 .068 \\
\hline America & 5.166 .362 & 10.439 .742 & 15.445 .325 & 4.552 .956 & 6.132 .489 & 10.921 .320 \\
\hline Asia & 12.174 .183 & 23.812 .995 & 35.252 .876 & 8.445 .952 & 17.762 .263 & 29.300 .826 \\
\hline
\end{tabular}

Source: OICA,2020

According to the data presented above, a trend of decreasing production activities in the mentioned areas can be observed. Looking at the data for 2019, it is possible to see a growth in production in all quarters presented. The growth trend stopped abruptly at the end of 2019 when the whole world became involved at the beginning of the pandemic to some extent. It is 
important to point out that not all countries immediately found themselves in a direct struggle with the health risks arising from this crisis.

Table 2. Variation in production levels by quarters

\begin{tabular}{|c|c|c|c|}
\hline \multirow{2}{*}{ Market } & \multicolumn{3}{|c|}{ Variation } \\
\cline { 2 - 4 } & $\mathbf{Q 1}$ & $\mathbf{Q 2}$ & $\mathbf{Q 3}$ \\
\hline Europe & $-16.9 \%$ & $-38.4 \%$ & $-29.3 \%$ \\
\hline America & $-11.9 \%$ & $-41.3 \%$ & $-29.3 \%$ \\
\hline Asia & $-30.6 \%$ & $-25.4 \%$ & $-16.9 \%$ \\
\hline
\end{tabular}

Source: OICA,2020

Production by quarters in 2020 points to the fact that we can talk about somewhat of a recovery trend that is partly a result of decentralization and restructuring of the supply chains themselves. Important assumptions can be made based on quartile variations, and they can best indicate the impact of the epidemic. Asian countries are the ones that suffered the biggest variations in the first quarter of 2020. That is by far the largest decline in production activities at that time. Such a situation is due to the fact that China was initially the focus of a pandemic, in which the situation was still not completely under control. As the pandemic progressed, so did the decline in countries in Europe and Asia, where the largest variations occurred during the second quarter. During the third quarter, the situation stabilized to some extent on all three continents, which is reflected by the decrease of negative values in production flows.

\section{FUTURE RESEARCH DIRECTIONS}

It can be said that supply chain partners play a major role in responding to crises along the chains, as essentially their export activities were the first to be affected by the pandemic. The suppliers' inability to deliver and the limited availability of raw materials are the primary reasons for problems in supply chain flows. Nearly half of the respondents in the survey said that the COVID-19 pandemic has had a "limited impact" on their operations, for example, a minor reduction in output due to reduced OEM demand, with greater resilience in Asia (China and Japan mainly) where $46 \%$ of respondents claimed the disruption was contained (IHS Markit, 2020). The indicator observer in the research refers to the percentage of suppliers who had to close their plants. Nearly $39 \%$ of all respondents were forced to close at least one plant (IHS Markit, 2020). The highest percentage of closed plants was in Wuhan, at the beginning of the epidemic. As the virus intensity in China dropped, the chances of creating poorer performances increased on European soil. The research showed that in Europe there is the biggest chance for potential interruptions in supply chains. Although supply problems arose directly from suppliers, it should be noted that the root cause of the problem lies in the direct impact of infection.

The research unequivocally indicated that although the primary problem arose in the health sector, strong logistics processes, and material management processes as well as their flexibility are the key to solving such problems. For this reason, agility combined with new technologies is seen as a key factor in defending chain vulnerabilities. According to the World Economic Forum, the activities that suppliers should carry out to mitigate the negative effects are shown in the next picture. 
Figure 1. Actions to mitigate short-term impact on your suppliers

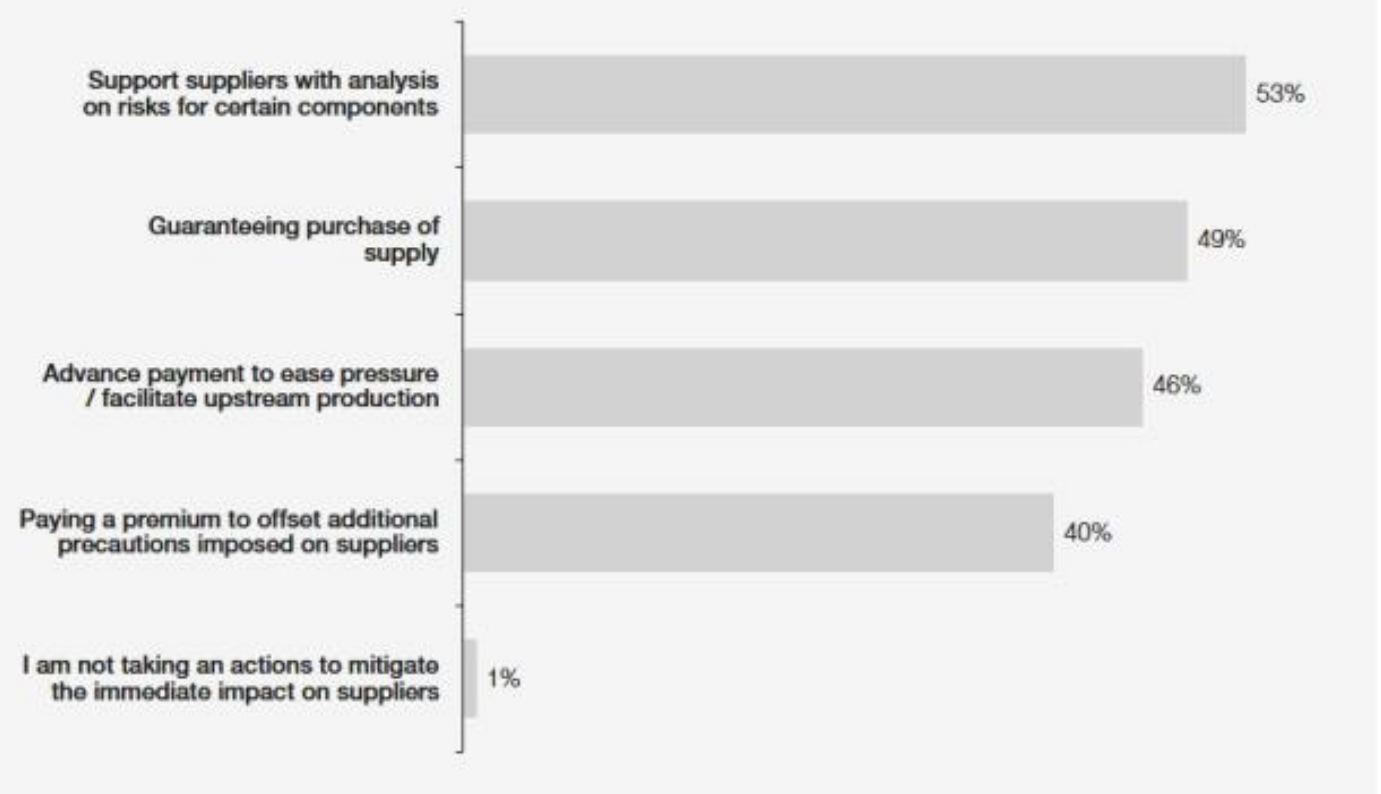

Source: WEF,2020

The essential recommendation refers to the development of such partnerships, which would include the coverage of protection costs, by the partners within the supply chains themselves. It is important to plan costs so that they reach a minimum at the supply chain level, while they are justifiably high within individual partners. The trade-off should provide optimal conditions for overcoming crises. The main issue arising from this crisis is what the structure of suppliers should look like, as well as what is their optimal number. Besides, the issue of their schedule and level of cooperation also became more important. The answers to these questions should provide new development opportunities in restructuring existing supply chains and building their resilience.

\section{CONCLUSION}

Based on everything that is written in this paper, it is possible to conclude that global automotive supply chains have been affected by the current pandemic. Due to not yet being able to determine all of the consequences, we can assume that the most pronounced impact in the automotive industry has not yet been confirmed. In order to reduce negative effects on production, it is necessary to restructure supply chains themselves, but also change relations with suppliers whose role is crucial in such a scenario. It is important to analyze new, more centralized business models at the supply chain level. Also, it is necessary to take into account the savings, define trade-offs and create optimal models that should be as accurate as possible. Getting acquainted with the changes, understanding the new role of the partners and detecting new tendencies is a step towards overcoming this crisis. Respecting these principles, as well as economic ones, will provide space for creating better business results.

\section{REFERENCES}

Ishida, S. (2020). Perspectives on supply chain management in a pandemic and the postCOVID-19 era. IEEE Engineering Management Review, 48(3), 146-152. https://doi.org/10.1109/EMR.2020.3016350 
Rio Chanona, R.M., Mealy, P., Pichler, A., Lafond, F., \& Doyne Farmer, J. (2020). Supply and demand shocks in the COVID-19 pandemic: an industry and occupation perspective. Oxford Review of Economic Policy, 36(1), 94-137. https://doi.org/10.1093/oxrep/graa033

Dasaklis, T., Pappis, C., \& Rachaniotis, N. (2012). Epidemics control and logistics operations: A review. International Journal of Production Economics, 139(2), 393-410. https://doi.org/10.1016/j.ijpe.2012.05.023

Ivanov, D. (2020). Predicting the impacts of epidemic outbreaks on global supply chains: A simulation-based analysis on the coronavirus outbreak (COVID-19/SARS-CoV-2) case. Transportation Research Part E: Logistics and Transportation Review, 136, 1-14. https://doi.org/10.1016/j.tre.2020.101922

Gereffi, G. (2020). What does the COVID-19 pandemic teach us about global value chains? The case of medical supplies. Journal of International Business Policy, 3, 287-301. https://doi.org/10.1057/s42214-020-00062-w

Brakman, S., Garretsen, H., \& Witteloostuijn, A. (2020). The turn from just-in-time to just-incase globalization in and after times of COVID-19: An essay on the risk re-appraisal of borders and buffers. Social Sciences and Humanities Open, 2(1), 1-6. https://doi.org/10.1016/j.ssaho.2020.100034

\section{ADDITIONAL READING}

KPMG. (2020). Covid-19: Impact on the automotive sector. Available: https://assets.kpmg/content/dam/kpmg/ar/pdf/2020/covid-19-impact-on-the-automotivesector.pdf [28.11.2020].

Accenture. (2020). COVID-19: Mobilizing the automotive industry now. Available: https://www.accenture.com/be-en/insights/automotive/coronavirus-automotive-rapidresponse [29.11.2020].

ICLG. (2020). Impacts to Automotive Supply Chains From COVID-19. Available: https://iclg.com/briefing/11745-impacts-to-automotive-supply-chains-from-covid-19 [02.12.2020].

Global Supply Chain Law Blog. (2020). Impacts to Automotive Supply Chains from COVID19. Available: https://www.globalsupplychainlawblog.com/automotive/impacts-toautomotive-supply-chains-from-covid-19/ [08.12.2020].

IHS Markit. (2020). COVID-19 Pandemic Impact on Automotive Suppliers. Available: https://ihsmarkit.com/research-analysis/covid19-pandemic-impact-on-automotivesuppliers.html [10.12.2020].

OICA. (2020). Production statistics. Available: https://www.oica.net/category/productionstatistics/2019-statistics/ [11.12.2020].

WEF. (2020). How to rebound stronger from COVID-19? Resilience in manufacturing and supply systems. Available: http://www3.weforum.org/docs/WEF_GVC_the_impact_of_COVID_19_Report.pdf [15.12.2020]. 